\title{
Inhibition of Human Colon Cancer Cell Growth by Selective Inhibition of Cyclooxygenase-2
}

\author{
Hongmiao Sheng, ${ }^{\ddagger}$ Jinyi Shao, ${ }^{\star \ddagger}$ Susan C. Kirkland, ${ }^{\star \star}$ Peter Isakson, ${ }^{\mathbb{I}}$ Robert J. Coffey, ${ }^{\star \S \|}$ Jason Morrow, ${ }^{\star}$ \\ R. Daniel Beauchamp, ${ }^{\ddagger \S}$ and Raymond N. DuBois ${ }^{\star \otimes} \|$ \\ $*$ Department of Medicine, ${ }^{\ddagger}$ Department of Surgery, and ${ }^{\S}$ Department of Cell Biology, Vanderbilt University Medical Center and $\|^{\|} A$ \\ Medical Center, Nashville, Tennessee 37232; "Department of Inflammatory Disease Research, Searle R \& D, St. Louis, Missouri \\ 63198-0001; and **I.C.R.F. Histopathology Unit, Royal Postgraduate Medical School, University of London, London W12 ONN, \\ United Kingdom
}

\begin{abstract}
A considerable amount of evidence collected from several different experimental systems indicates that cyclooxygenase-2 (COX-2) may play a role in colorectal tumorigenesis. Large epidemiologic studies have shown a $40-50 \%$ reduction in mortality from colorectal cancer in persons taking aspirin or other nonsteroidal antiinflammatory drugs on a regular basis. One property shared by all of these drugs is their ability to inhibit COX, a key enzyme in the conversion of arachidonic acid to prostaglandins. Two isoforms of COX have been characterized, COX-1 and COX-2. COX-2 is expressed at high levels in intestinal tumors in humans and rodents. In this study, we selected two transformed human colon cancer cell lines for studies on the role of COX-2 in intestinal tumorigenesis. We evaluated $\mathrm{HCA}-7$ cells which express high levels of COX-2 protein constitutively and HCT-116 cells which lack COX-2 protein. Treatment of nude mice implanted with $\mathrm{HCA}-7$ cells with a selective COX-2 inhibitor (SC-58125), reduced tumor formation by 85-90\%. SC-58125 also inhibited colony formation of cultured HCA-7 cells. Conversely, SC-58125 had no effect on HCT-116 implants in nude mice or colony formation in culture. Here we provide evidence that there may be a direct link between inhibition of intestinal cancer growth and selective inhibition of the COX-2 pathway. (J. Clin. Invest. 1997. 99:2254-2259.) Key words: cyclooxygenase-2 • nonsteroidal antiinflammatory drug • colon cancer • chemoprevention
\end{abstract}

\section{Introduction}

Colorectal cancer is the second leading cause of death from cancer in the United States, claiming about 55,000 lives this year. Even with a better understanding of the genetic mutations involved in the development of colorectal cancer, treatment of advanced disease has not been promising. Increasing efforts are therefore being made towards developing more effective prevention and screening measures. Several recent

Address correspondence to Raymond N. DuBois, M.D., Ph.D., Department of Medicine/GI, MCN C-2104, Vanderbilt University Medical Center, Nashville, TN 37232-2279. Phone: 615-343-8989; FAX: 615-343-6229; E-mail: duboisrn@ctrvax.vanderbilt.edu

Received for publication 10 December 1996 and accepted in revised form 20 February 1997.

The Journal of Clinical Investigation

Volume 99, Number 9, May 1997, 2254-2259 studies have reported a $40-50 \%$ decrease in the relative risk of colorectal cancer in persons who are continuous users of aspirin or other nonsteroidal antiinflammatory drugs (NSAIDs) ${ }^{1}$ (1-6), suggesting that these drugs serve as effective cancer chemopreventive agents. However, prolonged use of NSAIDs results in untoward gastrointestinal side effects that are likely due to inhibition of gastric prostaglandin production, which play a crucial role in maintaining gastric mucosal integrity. One common target of action for this class of drugs is the enzyme cyclooxygenase (COX). Two isoforms of COX have been identified and are designated as COX-1 and COX-2 in this report. Most NSAIDs currently in use inhibit both COX-1 and COX-2 (7-10). COX-1 is expressed constitutively in a number of cell types and tissues, including gastric mucosa (11). In contrast, COX-2 belongs to a class of genes referred to as immediate early or early growth response genes which are expressed rapidly and transiently after stimulation of cultured cells by growth factors, cytokines, and tumor promoters (12, 13); COX-2 expression is thus elevated in inflammatory cells and sites of inflammation (14).

Previously, we have demonstrated increased COX-2 expression in human colorectal adenocarcinomas when compared with normal adjacent colonic mucosa (15); these findings have been confirmed by other investigators who have shown elevated levels of COX-2 protein in colorectal tumors by Western blotting (16) and immunohistochemical staining (17). We have also observed markedly elevated levels of COX-2 mRNA and protein in colonic tumors that develop in rodents after carcinogen treatment (18) and in adenomas taken from Min mice (19). Our observations of elevated COX-2 expression in three different models of colorectal carcinogenesis have led us to consider the possibility that COX-2 expression may be related to colorectal tumorigenesis in a causal way. A recent report has demonstrated a $40 \%$ reduction in aberrant crypt formation in carcinogen-treated rats given a selective COX-2 inhibitor (20). Another study has provided genetic evidence which directly links COX-2 expression to intestinal tumorigenesis $(21,22)$. This recent report (22) demonstrated that $\mathrm{APC}^{\Delta 716}$ mice develop hundreds of tumors per intestine. When these mice were bred with COX-2 null mice there was an $80-90 \%$ reduction in tumor multiplicity in the homozygous COX-2 null offspring. Additionally, when the APC ${ }^{\Delta 716}$ mice were treated with a highly selected COX-2 inhibitor, there was a marked reduction in tumor multiplicity. These results suggest that COX-2 may act as a tumor promoter in the intestine and that increased levels of COX-2 expression may result directly from disruption of the APC gene.

1. Abbreviations used in this paper: COX, cyclooxygenase; NSAID, nonsteroidal antiinflammatory drug. 
To address the hypothesis that COX-2 is involved in colorectal tumorigenesis we have evaluated the growth of human colon cancer cells (HCA-7) that constitutively express COX-2 in nude mice plus and minus treatment with a highly selective COX-2 inhibitor (SC-58125). Also, we have evaluated a colon cancer cell line (HCT-116) which lacks COX-2 expression to test for the selectivity of drug treatment. Both HCA-7 and HCT-116 cell lines were originally derived from human colonic carcinomas $(23,24)$. The HCA-7 cells were derived by Kirkland and co-workers in the United Kingdom and have been extensively characterized $(23,25-29)$. Recent work by our group has shown that the HCA-7 cells become polarized in culture and release prostaglandins in a vectorial fashion (30). The HCT-116 cells have been extensively characterized as well and these cells have been found to have a homozygous mutation at the hMLH1 locus and are poorly differentiated (24, 31-34).

Here we report that treatment with SC-58125 inhibits tumor growth by $85-90 \%$ in implanted HCA-7 cells, which have high COX-2 expression, but has no significant effect on implanted HCT-116 cells which lack COX-2 expression. These results suggest that COX-2 may be a feasible target for which to develop future agents for colon cancer prevention and treatment strategies.

\section{Methods}

Cell culture. For the cell growth studies, cells were treated with 10 , 25 , and $50 \mu \mathrm{M}$ of SC-58125, 1-[(4-methylsulfonyl)phenyl]-3-trifluoromethyl-5-[(4-fluoro) phenyl] pyrazole (G.D. Searle and Co., St. Louis, MO). Experimental controls were treated with DMSO only. The medium was replaced and the treatment was repeated every $2 \mathrm{~d}$. HCA-7 and HCT-116 cells were grown as described previously (29, 30, 35).

Prostaglandin production. Eicosanoids were quantified in media from cell incubations using stable isotope dilution techniques with gas chromatography negative ion chemical ionization-mass spectrometry as described $(30,36)$. The limits of sensitivity for detection of either $\mathrm{PGE}_{2}, \mathrm{PGD}_{2}, \mathrm{PGF}_{2 \alpha}$, or thromboxane $\mathrm{B}_{2}$ or 6-ketoPGF ${ }_{1 \alpha}$ is $4 \mathrm{pg} / \mathrm{ml}$.

Immunoblotting. Immunoblot analysis of cell protein lysates was performed as described previously (37). Briefly, the cells were lysed for $30 \mathrm{~min}$ in RIPA buffer ( $1 \times$ PBS, $1 \%$ Nonidet P-40, $0.5 \%$ sodium deoxycholate, $0.1 \%$ SDS, $10 \mathrm{mg} / \mathrm{ml}$ ) $0.1 \%$, then clarified cell lysates $(100 \mu \mathrm{g})$ were denatured and fractionated by $12.5 \%$ SDS-PAGE. The proteins were transferred to nitrocellulose filters after electrophoresis, and the filters were probed with an anti-human COX-2 antibody (Santa Cruz Biotechnology Inc., Santa Cruz, CA), developed by the ECL chemiluminescence system (Amersham, Arlington Heights, IL), and exposed to XAR5 film (Eastman Kodak, Rochester, NY). Quantitation was carried out by video densitometry.

Northern blotting. Total cellular RNA was extracted according to Chirgwin et al. (38). RNA samples $(20 \mu \mathrm{g} / \mathrm{lane})$ were separated on formaldehyde-agarose gels and blotted onto nitrocellulose filters. The blots were hybridized with cDNA probes labeled with $\left[\alpha-{ }^{32} \mathrm{P}\right] \mathrm{dCTP}$ by random primer extension. After hybridization and washes, the blots were then exposed to $\mathrm{x}$-ray film for autoradiography as described (37). 18S rRNA signals were used as internal controls to determine integrity of RNA and equality of loading among lanes.

Colony morphology. Cells were suspended in $0.5 \mathrm{ml}$ of $1: 2 \mathrm{di}-$ luted Matrigel (Collaborative Biomedical Products, Bedford, MA). Then the mixture was plated onto 24-well plates and treated with 10 , 25 , and $50 \mu \mathrm{M}$ of SC-58125. Treatment was repeated every $2 \mathrm{~d}$. Colony number was counted at the times indicated in each figure legend.

Tumor growth in nude mice. Cells were suspended in $0.2 \mathrm{ml}$ of DMEM medium and were injected into the dorsal subcutaneous tis- sue of athymic nude mice (Harlan Sprague Dawley, Inc., Indianapolis, IN). $10 \mathrm{mg} / \mathrm{kg}$ of SC-58125 was injected into peritoneal cavity of the mice before inoculation of cells. The treatment was continued three times a week at a dose of $5 \mathrm{mg} / \mathrm{kg}$. Tumor volume was determined by external measurement according to published methods (39). Volume was determined according to the equation $V=[L \times$ $\left.W^{2}\right] \times 0.5$, where $\mathrm{V}$ is volume, $\mathrm{L}$ is length, and $\mathrm{W}$ is width.

\section{Results}

Prostaglandin levels in HCA-7 and HCT-116 cells. In the studies reported here, we have characterized two human colon cancer cell lines (HCA-7 and HCT-116). HCT-116 cells produced no detectable $\mathrm{PGE}_{2}, 6 \mathrm{~K}-\mathrm{PGF}_{1 \alpha}, \mathrm{PGF}_{2 \alpha}, \mathrm{PGD}_{2}$, or $\mathrm{TXB}_{2}$, even in the presence of excess substrate with $10 \%$ serum, indicating a total absence of COX activity (data not shown). We measured $\mathrm{PGE}_{2}$ production by HCA-7 and HCT-116 cells in both the presence and absence of SC-58125 $(25 \mu \mathrm{M})$ and the results are summarized in Fig. 1. Therefore, these results indicated that we could not detect $\mathrm{PGE}_{2}$ production in the HCT116 cells, while $\mathrm{PGE}_{2}$ production was significant in the HCA-7 cells $(10 \mathrm{ng} / \mathrm{ml})$ and this was inhibited by SC-58125 treatment. Importantly, at the concentrations used in our study, SC-58125 has no inhibitory activity on COX-1 (14). Since selective inhibition of COX-2 results in almost complete inhibition of prostaglandin production, we predicted that the HCA-7 cells in culture expressed very low levels of COX-1.

Levels of $C O X-1$ and $C O X-2$ in HCA-7, HCT-116 cells, and xenografts. The HCA-7 cells in culture maintain high constitutive COX-2 expression, while the HCT-116 cells lack detectable COX-2 protein, although some clones from this cell line have been reported to express low levels of $\mathrm{COX}-2$ mRNA by PCR analysis (40). In this report we evaluate the effect of SC-58125 treatment on these two established human colon cancer cell lines. The HCA-7 cell line was shown previously to constitutively express COX-2 (30), which we confirmed by Western blot analysis shown in Fig. 2. We evaluated another human colorectal cancer cell line (HCT-116) and found that it lacked expression of the COX-2 protein (Fig. 2).

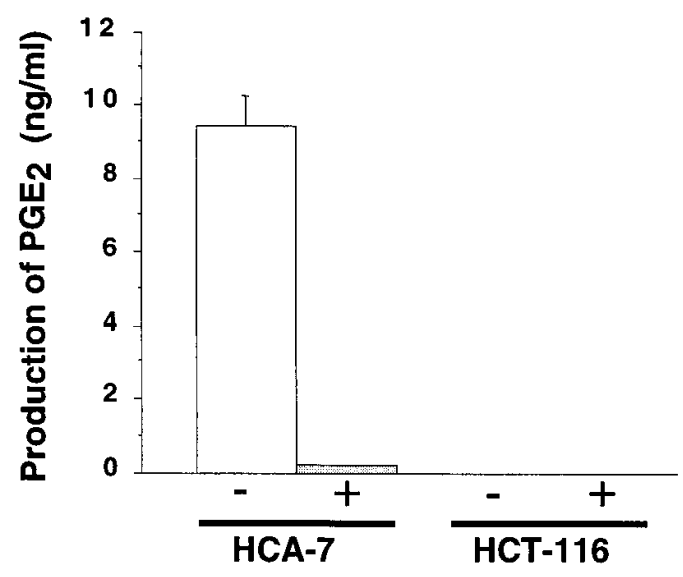

Figure 1. $\mathrm{PGE}_{2}$ production in HCA-7 and HCT-116 cells plus and minus SC-58125. $\mathrm{PGE}_{2}$ levels were measured in the media taken from either HCA-7 or HCT-116 cells by gas chromatography negative ion chemical ionization-mass spectrometry as described previously (30, 36). These measurements were taken $1 \mathrm{~h}$ after addition of excess arachidonate $(10 \mu \mathrm{M})$ in the presence or absence of SC-58125 $(25 \mu \mathrm{M})$. 


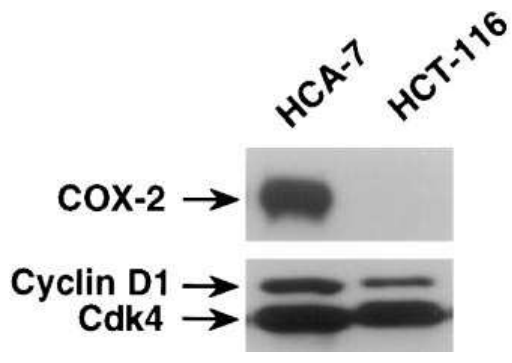

Figure 2. COX-2 expression levels in HCA-7 and HCT-116 colon cancer cells. Western blot analysis for COX-2 protein levels in HCA-7 and HCT-116 human colon cancer cells. Immunoblot analysis was carried out as described in Methods. $40 \mu \mathrm{g}$ of protein was electrophoresed in each lane. For COX-2 immunoblotting a rabbit anti-human COX-2 antibody was used at a 1:250 dilution (Santa Cruz Biotechnology Inc.). Other primary antibodies were as follows: polyclonal rabbit antiserum to human cyclin D1 (Upstate Biotechnology, Inc., Lake Placid, NY) was used at a 1:1,000 dilution and human cdk4 (Santa Cruz Biotechnology Inc.) was used at a 1:1,000 dilution.

We also measured levels of COX protein in the xenografts formed by these cell lines in the presence and absence of a selective COX-2 inhibitor, SC-58125. We found that COX-2 protein expression was maintained in the HCA-7 xenografts, although levels were slightly lower after treatment with SC58125 (Fig. 3 A). We could not detect COX-2 protein in the
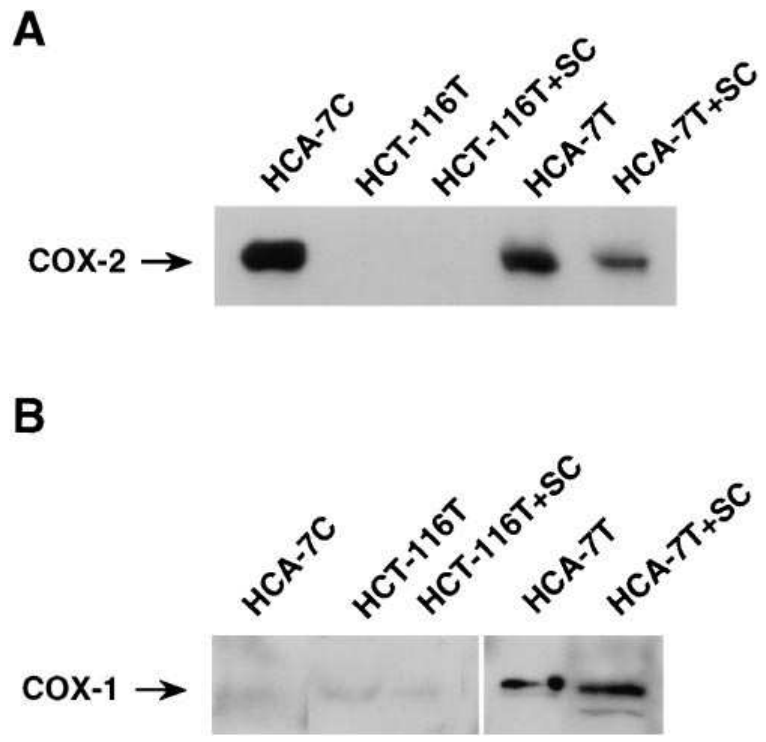

Figure 3. COX expression in HCA-7 and HCT-116 xenografts. HCA-7 and HCT- 116 cells were suspended in $0.2 \mathrm{ml}$ of DMEM medium and injected into the dorsal subcutaneous tissue of athymic nude mice. DMSO or an initial dose of $10 \mathrm{mg} / \mathrm{kg}$ of SC-58125 was injected into peritoneal cavity of the mice before inoculation of cells. The treatment was continued three times a week at a lower dose of $5 \mathrm{mg} / \mathrm{kg}$. The tumors were harvested at 30-40 d after injection and protein extracts were prepared and subjected to immunoblot analysis. $50 \mu \mathrm{g}$ of protein was electrophoresed in each lane. For COX-2 immunoblotting shown in $A$, a rabbit anti-human COX-2 antibody was used at a 1:250 dilution (Santa Cruz Biotechnology Inc.). For COX-1 immunoblotting shown in $B$, a rabbit anti-human COX-1 antibody was used at a 1:250 dilution (Santa Cruz Biotechnology Inc.). The result obtained from the cell line alone is marked with a " $\mathrm{C}$," the results for the tumors are marked with a "T," and the results for a tumor taken from an animal treated with SC-58125 are marked "+SC."
HCT-116 cells in culture nor in the xenografts formed by injecting these cells into nude mice (Fig. $3 A$ ). These results are consistent with our finding that these cells produce no detectable $\mathrm{PGE}_{2}$ in our assay system (Fig. 1). The HCT-116 xenografts did express very low levels of COX-1. Interestingly, the HCA-7 xenografts expressed much higher levels of the COX-1 protein than was present in the cultured cells (Fig. $3 \mathrm{~B}$ ), but these levels did not change after treatment of the mice with SC-58125. Work is underway to determine the cellular localization of both COX-1 and COX-2 in the xenografted tumors formed by both of these cell lines.

Growth in extracellular matrix components. We demonstrated previously that nontransformed intestinal epithelial cells are unable to survive when plated in extracellular matrix components, such as Matrigel (41). However, both HCA-7 and HCT-116 cells are able to form discrete colonies when plated in Matrigel (data not shown). Since one of the cell lines maintained COX-2 expression (HCA-7), and the other did not (HCT-116), we explored the effect of a selective COX-2 inhibitor (SC-58125) on colony growth. SC-58125 dramatically inhibited the size and number of colonies derived from the COX-2 expressing HCA-7 cells, but had no significant effect on colony size or number derived from the HCT-116 cells (Fig. 4).

Selective inhibition of $C O X-2$ inhibits solid tumor growth. Next, we evaluated the effect of SC-58125 on the growth of these two established human colon cancer cell lines (HCA-7 and HCT-116) when these cells were implanted as xenografts in nude mice. We first confirmed that both the HCA-7 and HCT-116 cell lines develop into solid tumors when implanted into nude mice (Fig. 5). Treatment of the nude mice with SC58125 inhibited tumor development by $90 \%$ for the HCA-7 implants by day 7 but had no significant effect on implants of
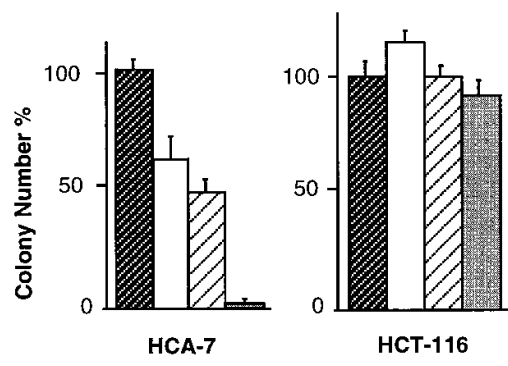

Figure 4. SC-58125 inhibition of colony formation by HCA-7 and HCT-116 human colon cancer cell lines. HCA-7 and HCT-116 growth in Matrigel was evaluated by suspending $2 \times 10^{4}$ cells $1: 2$ diluted in Matrigel. The mixture was then plated into $24-$ well plates. $0,10,25$, and $50 \mu \mathrm{M}$ of SC-58125 were added into the indicated wells. The control cells received only DMSO. The medium covering the cells with SC-58125 was replaced every $48 \mathrm{~h}$ at the concentrations indicated on the figure. Colony numbers and volume were determined manually using an inverted

microscope. The results were expressed as colony number per microscopic field $(\times 10)$. Black bar with white stripes, control; white bar, 10 $\mu \mathrm{M}$ SC-58125; white bar with black stripes, $25 \mu \mathrm{M}$ SC-58125; gray bar, $50 \mu \mathrm{M} \mathrm{SC}-58125$. 
A

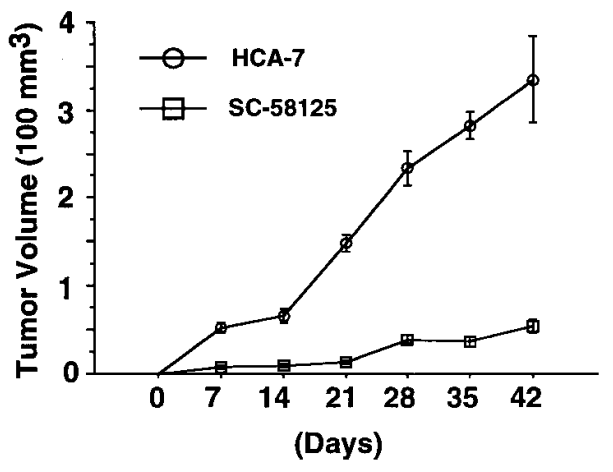

B

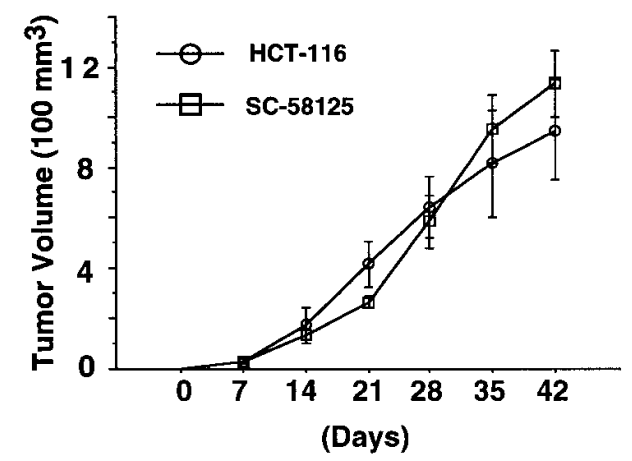

Figure 5. Growth curves of HCA-7 and HCT-116 implants in athymic nude mice. $10^{6}$ HCA-7 cells, shown in $A$, or HCT-116 cells, shown in $B$, were suspended in $0.2 \mathrm{ml}$ of DMEM medium and injected into the dorsal subcutaneous tissue of athymic nude mice. DMSO or an initial dose of $10 \mathrm{mg} / \mathrm{kg}$ of SC-58125 was injected into peritoneal cavity of the mice before inoculation of cells. The treatment was continued three times a week at a lower dose of $5 \mathrm{mg} / \mathrm{kg}$. Previously, it was shown that this dose of drug will result in complete inhibition of COX-2 enzyme activity in animal models for inflammation studies (14). Tumor volumes were determined by external measurement according to published methods (39). Volume was determined according to the equation $V=\left[L \times W^{2}\right] \times 0.5$, where $\mathrm{V}$ is volume, $\mathrm{L}$ is length, and $\mathrm{W}$ is width. Values expressed are the means \pm SE of 12 xenografts.

HCT-116 cells (Fig. 5). These experiments were conducted on 12 animals per time point for each group and have been reproduced in three separate sets of experiments. These data support the notion that SC-58125 inhibits tumor development of implants from COX-2-expressing colon cancer cells but not in cells that lack its expression and indicate that COX-2 activity may play a direct role in colorectal tumorigenesis in a set of colon cancers. Results from an evaluation of human colorectal cancers which occur spontaneously reveal that up to $80-85 \%$ maintain elevated COX-2 expression $(15,16)$. Therefore, the $15-20 \%$ of tumors which lack COX-2 expression may have lost their dependency on this pathway due to other genetic changes or alterations in signaling pathways. These experimental results provide evidence for a link between COX-2 expression and responsiveness to selective inhibition of the COX-2 pathway.

\section{Discussion}

There is now considerable evidence, from several different experimental systems, that COX-2 may play a role in the genesis of colorectal cancer $(20-22,41)$. Here we describe a link between inhibition of intestinal cancer growth and selective inhibition of the COX-2 pathway. This important information provides a clue as to one possible mechanism for cancer prevention by NSAIDs and will allow for the rationale design of future experiments to study the precise molecules and signal transduction pathways involved in this process.

$C O X-2$ expression and intestinal tumorigenesis. Recently, we reported that intestinal adenomas from Min mice express COX-2 mRNA and protein (19). Since others have shown that tumor multiplicity is dramatically decreased in Min mice treated with NSAIDs (42-44), our observation that COX-2 expression is elevated in early intestinal lesions from the Min mouse indicates that COX-2 may play a role early in tumorigenesis in this model. Numerous studies have reported that NSAIDs markedly reduce tumor multiplicity in rats treated with the carcinogen azoxymethane and one recent report indicates that selective COX-2 inhibition in these animals leads to a reduction in aberrant crypt formation (20). We also found that COX-2 levels are dramatically increased in intestinal tumors which develop in azoxymethane-treated Fisher-344 rats (18), but COX-2 was absent in normal appearing intestinal mucosa from these animals. Thus, in two independent animal model systems for intestinal tumorigenesis, COX-2 is elevated early in the sequence of events leading to malignant transformation.

Because there is circumstantial evidence linking COX-2 expression to intestinal tumorigenesis, we set out to test the hypothesis that COX-2 is involved directly in intestinal tumor development. In this report we chose to evaluate the response of two transformed intestinal epithelial cell lines to treatment with SC-58125, a selective COX-2 inhibitor. The HCA-7 cell line constitutively expresses the COX-2 gene. Treatment of HCA-7 cells with SC-58125 inhibited their growth in culture and as tumor implants in nude mice. The other cell line, HCT116, lacks COX-2 expression and in these cells SC-58125 had no effect on colony formation in culture or when they were implanted in nude mice. Other groups have reported antiproliferative effects of nonselective NSAIDs, used at very high concentrations, but these effects are not likely due to their inhibition of COX enzymes (45). Our result with the HCT-116 cells shows that SC-58125 is not acting as a nonspecific cytostatic agent, but has a selective effect on transformed cells expressing COX-2. Several factors are involved in colorectal carcinogenesis and it seems evident that some colorectal tumor cells (such as HCT-116) do not require COX-2 expression in order to maintain a transformed state. It is of interest to note that the HCT-116 cells are more poorly differentiated (33) than the HCA-7 cells (30) with respect to their ability to polarize in culture.

Clinical relevance. Colorectal cancer is the second leading cause of cancer deaths in the United States and the high mortality is due, in part, to the fact that by the time symptoms have developed the cancer has become metastatic. Currently, our best hope to reduce this high mortality is to develop better screening and prevention measures in order to detect the disease earlier or prevent it from developing. Currently, a new class of highly selective NSAIDs is being developed by phar- 
maceutical companies worldwide. These drugs, which include SC-58125 used here, are highly selective inhibitors of COX-2 and have little or no effect on COX-1 activity. In recent studies these drugs have been shown to have fewer side effects such as gastritis and ulcer disease, presumably due to their lack of COX-1 inhibition (14). Because of their effectiveness in inhibiting growth of intestinal adenocarcinoma xenografts in mice, these agents may deserve a careful evaluation in patients at very high risk for colorectal cancer, such as persons with familial colon cancer syndromes and patients who have been treated previously for sporadic colorectal adenomas or cancer.

\section{Acknowledgments}

We thank Brigid Hogan once again for her brilliant editorial assistance and Chris Williams for his input and assistance.

The authors would like to acknowledge support from the A.B. Hancock, Jr. Memorial Laboratory, Lucille P. Markey Charitable Trust, the United States Public Health Services (grants DK-47297 to R.N. DuBois, CA 46413 to R.J. Coffey, GM-53319 to R.D. Beauchamp, CA-69457 to R.D. Beauchamp, DK 48831 to J.D. Morrow, GM15431 to J.D. Morrow), and NIEHS-00267 and the Veterans Administration Merit Grant to R.N. DuBois. R.N. DuBois is a recipient of a Boehringer Ingelheim New Investigator Award, a Gastroenterology Research Group Young Investigator Award, and is an AGA Industry Research Scholar. R.J. Coffey is a VA Clinical Investigator.

\section{References}

1. Giovannucci, E., E.B. Rimm, M.J. Stampfer, G.A. Colditz, A. Ascherio, and W.C. Willett. 1994. Aspirin use and the risk for colorectal cancer and adenoma in male health professionals. Ann. Intern. Med. 121:241-246.

2. Giovannucci, E., K.M. Egan, D.J. Hunter, M.J. Stampfer, G.A. Colditz, W.C. Willett, and F.E. Speizer. 1995. Aspirin and the risk of colorectal cancer in women. N. Engl. J. Med. 333:609-614.

3. Marnett, L.J. 1992. Aspirin and the potential role of prostaglandins in colon cancer. Cancer Res. 52:5575-5589.

4. Thun, M.J., M.M. Namboodiri, and C.W.J. Heath. 1991. Aspirin use and reduced risk of fatal colon cancer. N. Engl. J. Med. 325:1593-1596.

5. Thun, M.J., M.M. Namboodiri, E.E. Calle, W.D. Flanders, and C.W.J. Heath. 1993. Aspirin use and risk of fatal cancer. Cancer Res. 53:1322-1327.

6. Marnett, L.J. 1995. Aspirin and related nonsteroidal anti-inflammatory drugs as chemopreventive agents against colon cancer. Prev. Med. 24:103-106.

7. Meade, E.A., W.L. Smith, and D.L. DeWitt. 1993. Differential inhibition of prostaglandin endoperoxide synthase (cyclooxygenase) isozymes by aspirin and other non-steroidal anti-inflammatory drugs. J. Biol. Chem. 268:6610-6614.

8. Laneuville, O., D.K. Breuer, D.L. Dewitt, T. Hla, C.D. Funk, and W.L. Smith. 1994. Differential inhibition of human prostaglandin endoperoxide $\mathrm{H}$ synthases-1 and -2 by nonsteroidal anti-inflammatory drugs. J. Pharmacol. Exp. Ther. 271:927-934.

9. O'Neill, G.P., J.A. Mancini, S. Kargman, J. Yergey, M.Y. Kwan, J.P. Falgueyret, M. Abramovitz, B.P. Kennedy, M. Ouellet, W. Cromlish, et al. 1994. Overexpression of human prostaglandin $\mathrm{G} / \mathrm{H}$ synthase-1 and -2 by recombinant vaccinia virus: inhibition by nonsteroidal anti-inflammatory drugs and biosynthesis of 15-hydroxyeicosatetraenoic acid. Mol. Pharmacol. 45:245-254.

10. Gierse, J.K., S.D. Hauser, D.P. Creely, C. Koboldt, S.H. Rangwala, P.C. Isakson, and K. Seibert. 1995. Expression and selective inhibition of the constitutive and inducible forms of human cyclo-oxygenase. Biochem. J. 305:479-484.

11. Williams, C.W., and R.N. DuBois. 1996. Prostaglandin endoperoxide synthase: why two isoforms? Am. J. Physiol. 270:G393-G400.

12. Nathans, D., L.F. Lau, B. Christy, S. Hartzell, Y. Nakabeppu, and K. Ryder. 1988. Genomic response to growth factors. Cold Spring Harbor Symp. Quant. Biol. 53:893-900.

13. Herschman, H.R. 1991. Primary response genes induced by growth factors and tumor promoters. Ann. Rev. Biochem. 60:281-319.

14. Masferrer, J.L., B.S. Zweifel, P.T. Manning, S.D. Hauser, K.M. Leahy, W.G. Smith, P.C. Isakson, and K. Seibert. 1994. Selective inhibition of inducible cyclooxygenase-2 in vivo is antiinflammatory and nonulcerogenic. Proc. Natl. Acad. Sci. USA. 91:3228-3232.

15. Eberhart, C.E., R.J. Coffey, A. Radhika, F.M. Giardiello, S. Ferrenbach, and R.N. DuBois. 1994. Up-regulation of cyclooxygenase 2 gene expression in human colorectal adenomas and adenocarcinomas. Gastroenterology. 107:1183-1188.
16. Kargman, S., G. O’Neill, P. Vickers, J. Evans, J. Mancini, and S. Jothy. 1995. Expression of prostaglandin G/H synthase-1 and -2 protein in human colon cancer. Cancer Res. 55:2556-2559.

17. Sano, H., Y. Kawahito, R.L. Wilder, A. Hashiramoto, S. Mukai, K. Asai, S. Kimura, H. Kato, M. Kondo, and T. Hla. 1995. Expression of cyclooxygenase-1 and -2 in human colorectal cancer. Cancer Res. 55:3785-3789.

18. DuBois, R.N., A. Radhika, B.S. Reddy, and A.J. Entingh. 1996. Increased cyclooxygenase-2 levels in carcinogen-induced rat colonic tumors. Gastroenterology. 110:1259-1262.

19. Williams, C.W., C. Luongo, A. Radhika, T. Zhang, L.W. Lamps, L.B. Nanney, R.D. Beauchamp, and R.N. DuBois. 1996. Elevated cyclooxygenase-2 levels in Min mouse adenomas. Gastroenterology. 111:1134-1140.

20. Reddy, B.S., C.V. Rao, and K. Seibert. 1996. Evaluation of cyclooxygenase-2 inhibitor for potential chemopreventive properties in colon carcinogenesis. Cancer Res. 56:4566-4569.

21. Prescott, S.M., and R.L. White. 1996. Self promotion? Intimate connections between APC and prostaglandin H synthase-2. Cell. 87:783-786.

22. Oshima, M., J.E. Dinchuk, S.L. Kargman, H. Oshima, B. Hancock, E. Kwong, J.M. Trzaskos, J.F. Evans, and M.M. Taketo. 1996. Suppression of intestinal polyposis in APC ${ }^{\Delta 716}$ knockout mice by inhibition of cyclooxygenase-2 (COX-2). Cell. 87:803-809.

23. Lampert, I.A., S. Kirkland, S. Farrell, and L.K. Borysiewicz. 1985. HLA-DR expression in a human colonic carcinoma cell line. J. Pathol. 146:337344

24. Brattain, M.G., W.D. Fine, F.M. Khaled, J. Thompson, and D.E. Brattain. 1981. Heterogeneity of malignant cells from a human colonic carcinoma. Cancer Res. 41:1751-1756.

25. Kirkland, S.C. 1985. Dome formation by a human colonic adenocarcinoma cell line (HCA-7). Cancer Res. 45:3790-3795.

26. Kirkland, S.C., K. Henderson, D. Liu, and M. Pignatelli. 1995. Organisation and gel contraction by human colonic carcinoma (HCA-7) sublines grown in 3-dimensional collagen gel. Int. J. Cancer. 60:877-882.

27. MacVinish, L.J., R.J. Pickles, and A.W. Cuthbert. 1993. Cyclic AMP and $\mathrm{Ca}^{2+}$ interactions affecting epithelial chloride secretion in human cultured colonic epithelia. Br. J. Pharmacol. 108:462-468.

28. Henderson, R.M., M.L. Ashford, L.J. MacVinish, and A.W. Cuthbert. 1992. Chloride channels and anion fluxes in a human colonic epithelium (HCA-7). Br. J. Pharmacol. 106:109-114.

29. Marsh, K.A., G.W. Stamp, and S.C. Kirkland. 1993. Isolation and characterization of multiple cell types from a single human colonic carcinoma: tumorigenicity of these cell types in a xenograft system. J. Pathol. 170:441-450.

30. Coffey, R.J., C.J. Hawkey, L. Damstrup, R. Graves-Deal, V.C. Daniel, P.J. Dempsey, R.N. DuBois, T. Jetton, and J. Morrow. 1997. EGF receptor activation induces nuclear targeting of COX-2, basolateral release of prostaglandins and mitogenesis in polarizing colon cancer cells. Proc. Natl. Acad. Sci. USA. 94:657-662.

31. Papadopoulos, N., N.C. Nicolaides, Y.F. Wei, S.M. Ruben, K.C. Carter, C.A. Rosen, W.A. Haseltine, R.D. Fleischmann, C.M. Fraser, M.D. Adams, et al. 1994. Mutation of a mutL homolog in hereditary colon cancer. Science (Wash. DC). 263:1559-1560.

32. Koi, M., A. Umar, D.P. Chauhan, S.P. Cherian, J.M. Carethers, T.A Kunkel, and C.R. Boland. 1994. Human chromosome 3 corrects mismatch repair deficiency and microsatellite instability and reduces $N$-methyl- $N^{\prime}$-nitro- $N$ nitrosoguanidine tolerance in colon tumor cells with homozygous hMLH1 mutation. Cancer Res. 54:4308-4312.

33. Ramesh, G., and A.E. Levine. 1995. Pro-transforming growth factoralpha processing in human colon carcinoma cells: role of protein kinase C. Int. J. Cancer. 62:492-497.

34. Levine, A.E. 1994. Involvement of protein kinase C and an elastase-like enzyme in the processing of transforming growth factor-alpha in human colon carcinoma cell lines. Int. J. Cancer. 58:129-134.

35. Groden, J., G. Joslyn, W. Samowitz, D. Jones, N. Bhattacharyya, L. Spirio, A. Thliveris, M. Robertson, S. Egan, M. Meuth, and R. White. 1996. Response of colon cancer cell lines to the introduction of APC, a colon-specific tumor suppressor gene. Cancer Res. 55:1531-1539.

36. DuBois, R.N., J. Awad, J. Morrow, L.J. Roberts, and P.R. Bishop. 1994. Regulation of eicosanoid production and mitogenesis in rat intestinal epithelial cells by transforming growth factor- $\alpha$ and phorbol ester. J. Clin. Invest. 93:493498.

37. DuBois, R.N., J. Shao, H. Sheng, M. Tsujii, and R.D. Beauchamp. 1996. $\mathrm{G}_{1}$ delay in intestinal epithelial cells overexpressing prostaglandin endoperoxide synthase-2. Cancer Res. 56:733-737.

38. Chirgwin, J.M., A.E. Przybyla, R.J. MacDonald, and W.J. Rutter. 1979. Isolation of biologically active ribonucleic acid from sources enriched in ribonuclease. Biochemistry. 18:5294-5299.

39. Wang, J., L. Sun, L. Myeroff, X. Wang, L.E. Gentry, J. Yang, J. Liang, E. Zborowska, S. Markowitz, J.K. Willson, and M.G. Brattain. 1995. Demonstration that mutation of the type II transforming growth factor beta receptor inactivates its tumor suppressor activity in replication error-positive colon carcinoma cells. J. Biol. Chem. 270:22044-22049.

40. Kutchera, W., D.A. Jones, N. Matsunami, J. Groden, T.M. McIntyre, G.A. Zimmerman, R.L. White, and S.M. Prescott. 1996. Prostaglandin H syn- 
thase-2 is expressed abnormally in human colon cancer: evidence for a transcriptional effect. Proc. Natl. Acad. Sci. USA. 93:4816-4820.

41. Tsujii, M., and R.N. DuBois. 1995. Alterations in cellular adhesion and apoptosis in epithelial cells overexpressing prostaglandin endoperoxide synthase-2. Cell. 83:493-501.

42. Beazer-Barclay, Y., D.B. Levy, A.R. Moser, W.F. Dove, S.R. Hamilton, B. Vogelstein, and K.W. Kinzler. 1996. Sulindac suppresses tumorigenesis in the min mouse. Carcinogenesis. 17:1757-1760.

43. Jacoby, R.F., D.J. Marshall, M.A. Newton, K. Novakovic, K. Tutsch, C.E. Cole, R.A. Lubet, G.J. Kellof, A. Verma, A.R. Moser, and W.F. Dove. 1996. Chemoprevention of spontaneous intestinal adenomas in the Apc ${ }^{\mathrm{Min}}$ mouse model by the nonsteroidal anti-inflammatory drug piroxicam. Cancer Res. 56:710-714.

44. Boolbol, S.K., A.J. Dannenberg, A. Chadburn, C. Martucci, X.J. Guo, J.T. Ramonetti, M. Abreu-Goris, H.L. Newmark, M.L. Lipkin, J.J. DeCosse, and M.M. Bertagnolli. 1996. Cyclooxygenase-2 overexpression and tumor formation are blocked by sulindac in a murine model of familial adenomatous polyposis. Cancer Res. 56:2556-2560.

45. Piazza, G.A., A.L. Rahm, M. Krutzsch, G. Sperl, N.S. Paranka, P.H Gross, K. Brendel, R.W. Burt, D.S. Alberts, R. Pamukcu, and D.J. Ahnen. 1995. Antineoplastic drugs sulindac sulfide and sulfone inhibit cell growth by inducing apoptosis. Cancer Res. 55:3110-3116. 